\title{
A case of pigmented purpuric dermatosis similar to mycosis fungoides
}

\author{
Koray Durmaz $^{1}$, Arzu Ataseven ${ }^{1 *}$, İlkay Özer ${ }^{1}$, and Pembe Oltulu ${ }^{2}$ \\ ${ }^{1}$ Necmettin Erbakan University, Meram Faculty of Medicine, Department of Dermatology, Konya, Turkey \\ ${ }^{2}$ Necmettin Erbakan University, Meram Faculty of Medicine, Department of Pathology, Konya, Turkey
}

\begin{abstract}
Pigmented purpuric dermatoses (PPD) characterized a group of capillaritis of obscure aetiology, manifested by localized or generalized, pigmented, petechial eruption. A purpuric eruption may be an unusual early manifestation of mycosis fungoides (MF), and also PPD may, occasionally, evolve to cutaneous T-cell lymphoma. We present the case of an 82-year-old male patient to emphasize the importance of this distinction.
\end{abstract}

\section{Introduction}

Pigmented purpuric dermatoses (PPD), are characterized as a group of dermatoses with brown or yellow petechia and sometimes with telangiectasia and dissociated with the venous deficiency or hematologic disorders [1-3]. A capillaritis group of subtypes with different morphologies, for which the reason is unknown. Mycosis fungoides (MF) can raise as pigmented purpuric dermatoses clinically, and similarly PPD patients can transform into MF in the follow-ups. Also, this situation exists histologically. It is currently believed that PPDs' endures in a monoclonal $\mathrm{T}$ cell population and is likely to progress to the MF [4].

\section{Case report}

Male patient, 82 years old, have been itching on periumblical area about 1.5 years and had purpuric patchy lesions on bilateral lower extremity lateral and extensor faces for five months. In the physical examination, there was no sign of lymphadenopathy and hepatosplenomegaly. Abdominal ultrasound, soft tissue ultrasound, blood smear test and some tumour markers was normal too.

In the biopsy samples, minimal acanthosis, spongiosis and focal parakeratosis in stratified squamous epithelium, vessel structures have swollen lumens filled with erythrocytes and intense erythrocytes extravasation, melanophages, lymphocytic infiltration in dermis were observed. The ratio of CD4/CD8 within the epithelium in large number of observed lymphocytes approximately 2 and loss of CD5 expression was $5 \%$.

There was no considerable atypical microscopic finding. Lymphocytes within ephitelium were inferred to be exocytosis. At the end, these histopathologic and patient's clinically findings were determined to be in harmony with PPD (Schamberg). The patient was treated with corticosteroid, emollient topically and systemic antihistamines. The patient was recovered by these treatments, his itching complaints and PPD lesions were completely resolved at the end of first month of the treatment.

\section{Discussion}

MF is the most important disease that must be separated from PPDs' as clinically and histopathologically. In a study, the pathologic pattern related with MF was identified in 29 out of 56 biopsy samples taken due to PPD [4]. In various studies, PPD patients' T cell monoclonality was reported as similar to MF [5]. The authors stated that the patients who diagnosed as PPD with monoclonality were more likely to have similar clinical and pathological features to mycosis fungoides and that PPD could represent a form of cutaneous T-cell lymphoid discranscription [6].

PPDs', that do not effect prognosis and treatment, are the common name for the various patterns of same illness. All of these subgroups display similar histopathology. This term includes Schamberg disease, Majocchi disease, pigmented purpuric lichenoid dermatosis of Gougerot and Blum, itching purpura, eczematid like purpura of Doucas and Kapetanakis, lichen aureus [7]. Though the etiopathogenesis of PPDs' is not clearly known, it was reported to be triggered by the various factors such as hypertension, diabetes mellitus, venous stasis, strenuous exercise, capillary fragility, focal infections, and chemical substance consumption [8]. The most common form of PPD is Schamberg's disease (progressive pigmented purpuric dermatosis) and it is characterized as asymptomatic lesions with reddish-brown patches and red-brown punctuation which resembling red pepper pods are found around these lesions. In general, lesions immediately progress on one leg or two. But, it may be observed on thighs, hips, upper extremities and body. It shows a chronic period with relapses and remissions. The initial age of disease on average is the fifth decades $[1,2,9]$. There is no a proved choice available for treatment. Pruritus

Correspondence to: Arzu Ataseven, Necmettin Erbakan University, Meram Faculty of Medicine, Department of Dermatology, Konya, Turkey, Tel: 905056915859; Fax: 0 3323236723; E-mail: arzuataseven@hotmail.com

Key words: mycosis fungoides, pigmented purpuric dermatosis

Received: March 08, 2017; Accepted: April 06, 2017; Published: April 13, 2017 
can be lightened through the use of topical corticosteroids and systemic antihistamines effects. Related venous stasis is to be treated with compressed socks. The use of narrow-band UVB and psoralen UVA was demonstrated as an effective treatment for some patients with PPD [10-14]. This study shows that purpuric pigmented dermatitis can be associated to or evolve into lymphoproliferative disease and mycosis fungoides. Mycosis fungoides and PPD are similar so this the clinician should be suspected when purpuric pigmented dermatitis is extensive, long-lasting ( $>1$ year), has a reticular arrangement and negative patchtesting [15].

\section{References}

1. Schioeder T (2003) Pigmented purpuric dermatoses. Fizpatrick's Dermatology in General Medicine. (6th edtn). McGraw-Hill, New York. Pp. 1735-1739.

2. Tristani-Firouzi P, Meadows KP, vanderhooft S (2001) Pigmented purpuric eruptions of childhood: a series of cases and review of literature. Pediatr Dermatol 18: 299-304. [Crossref]

3. Erkek E, Tunçez F, Kurtipek GS, Bagci Y (2003) Pigmente purpuric erupsiyonlar. Mersin Üniversitesi Tip Fakültesi Dergisi 4: 410-413.

4. Toro JR, Sander CA, LeBoit PE (1997) Persistent pigmented purpuric dermatitis and mycosis fungoides: simulant, precursor, or both? A study by light microscopy and molecular methods. Am J Dermatopathol 19: 108-118. [Crossref]

5. Fink-Puches R, Wolf P, Kerl H, Cerroni L (2008) Lichen aureus: clinicopathologic features, natural history, and relationship to mycosis fungoides. Arch Dermatol 144: 1169-1173. [Crossref]
6. Magro CM, Schaefer JT, Crowson AN, Li J, Morrison C (2007) Pigmented purpuric dermatosis: classification by phenotypic and molecular profiles. Am J Clin Pathol 128: 218-229. [Crossref]

7. Hoesly FJ, Huerter CJ, Shehan JM (2009) Purpura annularis telangiectodes of Majocchi: case report and review of the literature. Int J Dermatol 48: 1129-1133. [Crossref]

8. Kim DH, Seo SH, Ahn HH, Kye YC, Choi JE (2015) Characteristics and Clinical Manifestations of Pigmented Purpuric Dermatosis. Ann Dermatol 27: 404-410. [Crossref]

9. Sardana K, Sarkar R, Sehgal VN (2004) Pigmented purpuric dermatoses: an overview. Int $J$ Dermatol 43: 482-488. [Crossref]

10. Kim SK, Kim EH, Kim YC (2009) Treatment of pigmented purpuric dermatosis with topical photodynamic therapy. Dermatology 219: 184-186. [Crossref]

11. Wong WK, Ratnam KV (1991) A report of two cases of pigmented purpuric dermatoses treated with PUVA therapy. Acta Derm Venereol 71: 68-70. [Crossref]

12. Seckin D, Yazici Z, Senol A, Demircay Z (2008) A case of Schamberg's disease responding dramatically to PUVA treatment. Photodermatol Photoimmunol Photomed 24: 95-96. [Crossref]

13. Lasocki AL, Kelly RI (2008) Narrowband UVB therapy as an effective treatment for Schamberg's disease. Australas J Dermatol 49: 16-18. [Crossref]

14. Dhali TK, Chahar M, Haroon MA (2015) Phototherapy as an effective treatment for Majocchi's disease--case report. An Bras Dermatol 90: 96-99. [Crossref]

15. Lipsker D, Cribier B, Heid E, Grosshans E (1999) [Cutaneous lymphoma manifesting as pigmented, purpuric capillaries]. Ann Dermatol Venereol 126: 321-326. [Crossref]

Copyright: ( 02017 Durmaz K. This is an open-access article distributed under the terms of the Creative Commons Attribution License, which permits unrestricted use, distribution, and reproduction in any medium, provided the original author and source are credited. 